\title{
Frost resistance and Pseudomonas
}

\author{
A professor of biophysics and medical physics at the University of California, Berkeley, reflects on the \\ arguments that have halted the ice-minus tests.
}

For many decades, plant geneticists have worked to develop frost-resistant strains and varieties of crop plants. In this general endeavour, a novel weapon has recently been proposed: the dispersal of strains of bacteria from which the gene for ice nucleation protein ${ }^{1}$ has been removed. The bacteria are Pseudomonas syringae and Pseudomonas fluorescens, which occur naturally in forms that are ice-nucleationactive (INA), containing the functional gene, and ice-minus (INA ${ }^{-}$).

Pseudomonads are non-spore-forming psychrophilic saprophytes, universally dispersed in soil, water and food. Some cause plant diseases. One widespread species, Pseudomonas aeruginosa, is occasionally infective in animals, but such infections are rare. Ps. syringae does not grow at $37^{\circ} \mathrm{C}$ and is non-infective. Other species are familiar in food spoilage, causing, for example, the earthy and ammoniacal flavour of stale meat.

A field test of INA ${ }^{-}$Ps. syringae and fluorescens, applied to 2,400 blossoming strawberry plants, has been scheduled by Advanced Genetic Sciences (AGS), a biotechnology company ${ }^{2}$. The test would, it is hoped, pre-empt the ice-formers by the ice-minus strain. Approval of this field experiment was given by the US Environmental Protection Agency after prolonged deliberation and the inclusion of extensive safeguards.

The length of the growing period, which decides whether a crop can be produced, is the number of days between the last and first killing frosts in spring and autumn respectively. Data are compiled by the US Department of Agriculture for every county in the United States ${ }^{3}$. Frost prevents dent corn (maize) from ripening in northern latitudes, notably in Canada.

The search for frost resistance is not new, but was dramatized by the spurious claims of the Soviet charlatan Lysenko, who asserted in the 1950 s that his methods would make it possible to produce frostresistant wheat. This led in Siberia "to extremely low yields and sometimes complete destruction of the crop by frost" But the greatest dramatization of frost resistance was a reality. Canadian plant breeders produced a new strain of wheat, named Marquis, in 1904. Three years later, in Saskatchewan, Marquis wheat plants in a small experimental plot survived a killing frost on 12 September $1907^{5}$. As a result, Marquis pushed wheat farming northward into the rich black soil of the prairie provinces, previously untilled, and Canada was able to send millions of bushels of wheat to China in the 1950s.

I looked forward to news of ice-minus Pseudomonas. To my surprise, I learned that a protest demonstration would take place on 15 January on my doorstep. (I work on the fourth floor of a University of California building, of which the third floor is leased to AGS.) The demonstrators, organized by "East Bay Greens" and "Earth First!", distributed a leaflet couched in inflammatory terms alleging that "this genetically altered bacteria (sic), if established on Kudzu, could render thousands of acres of agricultural land virtually useless within a few years, and eventually dominate the eastern landscape". I pointed out to a demonstrator that, if the Kudzu plant, an "escaped" weed of Asian origin, could be so easily frost-proofed, the same could happen to tomato plants in Montana and orange trees in Florida, but I was informed that too much food was being produced anyway. The leaflet also said that once they escape, one-celled organisms can cause more death and destruction than all the wars we have ever fought, and it continued:

We oppose the release of these genetically altered organisms into the environment. We oppose the research that has created this technology as morally bankrupt and motivated by higher profits... It is not for our scientists, bureaucrats and industrialists to play God, or endanger us with technology that no one understands. While this experiment may prove safe in the end, what of the many thousands that are sure to follow, and the few that ultimately fail? The risks are not being adequately addressed, nor are the pressing moral issues that this type of technology raises.

I commented to an interlocutor that onecelled organisms always escape, that the profit motive in agriculture often leads to development of new technology that helps feed people everywhere, that the organisms did not effectively or essentially differ from ice-minus strains occurring normally in the environment, that this experiment did not involve "technology that no one understands" and that each experiment should be judged on its own merits rather than on the basis of "many thousands that are sure to follow". I also remarked that aiding the production of food was a moral issue. But the demonstrators then started to chant slogans and wave placards for the benefit of the television cameras and news reporters. One placard stated, "We don't need no designer genes". A leader of the group read a telegram from 27 German Bundestag members alleging that "our health and environment must not be sacrificed".

I was given a leaflet saying that "Green politics" seeks a "humane, just, democratic, peaceful, and ecologically sustainable world for ourselves and our children", with which I agree. But I do not understand why what seems to be harmless procedure for increasing the yields of produce is incompatible with this goal, especially since we are told to eat more fruit and vegetables to protect the health of ourselves and our children. But apparently there is no relenting.

In a local newspaper report on the demonstration, a representative of "Earth First!" stated that "This is very similar to the first atmospheric test of the atom bomb. Nuclear physicists who created the bomb had the "feeling that their actions could possibly ring down the curtain on humanity" ". Since a bucketful of ordinary dirt contains as many pseudomonads as would be used in the proposed experiment, either our species will disappear in the next minor dust storm, or the statement is nonsensical, probably the latter.

The hearings in Salinas, Monterey County, on 27 January, predictably led to a "postponement" of the scheduled test. According to USA Today, "school trustee Judy Pennycook said: 'There is no way north Monterey County can be considered remote. There are 30,000 people there', and 'We're playing environmental roulette', said tree farmer Glenn Church." According to Jeremy Rifkin, who is busily filing suits to block the experiments, the modified bacteria "may decrease rainfall". But it would seem that naturally occurring $\mathrm{INA}^{-}$are currently in equilibrium with the INA forms, and Rifkin's assertion was contradicted by $\mathbf{R}$. Schnell, a meteorologist.

I perceive a ritualistic rather than scientific attitude by opponents of the test, and I see no tendency by them to consider benefits as weighed against what seems to be a well-evaluated and minuscule risk.

Thomas H. Jukes

1. Green, R.L. \& Warren. G.J. Nature 317, 645-648 (1985).

2. Palca, J. Nature 319. 284 (1986).

. Climate and Man, USDA Yearbook of Agriculture (Superintendent of Documents. Washington. DC, 1941).

4. Medvedev. Z.A. The Rise and Fall of T.D. Lysenko (ColMedvedev. Z.A. The Rise and Fall of T.D.
umbia University Press. New York, 1969).

5. deKruif. P. Hunger Fighters (Harcourt, Brace, Jovanovich. New York, 1928)

6. Grass Roots 14, 1, 29 January - 11 February (2002 Blake Street, Berkeley. California 94704, 1986). 